\title{
USAHA MENINGKATKAN HASIL BELAJAR MATEMATIKA DENGAN MENERAPKAN STRATEGI PEMBELAJARAN STUDENT RECAP PADA PESERTA DIDIK PADA KELAS IXA MTs NEGERI 6 SLEMAN
}

\author{
Hj. SUTARTI \\ MTs Negeri 6 Sleman, D.I Yogyakarta \\ trtsutarti@gmail.com
}

\begin{abstract}
ABSTRAK
Artikel PTK ini membahas tentang efektivitas penerapan strategi pembelajaran Student Recap dalam meningkatan hasil belajar matematika peserta didik dengan bertujuan untuk mengetahui bagaimana (1) Hasil belajar matematika peserta didik yang diajar tanpa menggunakan strategi pembelajaran student recap pada kelas IX MTs Negeri 6 Sleman Kab. Sleman, (2) Hasil belajar matematika peserta didik yang diajar menggunakan strategi pembelajaran student recap pada kelas IX MTs Negeri 6 Sleman Kab. Sleman, (3) Apakah penerapan strategi pembelajaran student recap efektif dalam meningkatkan hasil belajar matematika peserta didik kelas IX MTs Negeri 6 Sleman Kab. Sleman. Penelitian ini merupakan jenis penelitian quasi experiment dengan desain penelitian non-equivalent control group design. Populasi penelitian ini adalah seluruh peserta didik kelas IX MTs Negeri 6 Sleman Kab. Sleman yang berjumlah 98 peserta didik terdiri atas kelas IX $_{1}$ sampai dengan kelas $\mathrm{IX}_{3}$. Sampel dalam penelitian ini adalah kelas $\mathrm{IX}_{3}$ sebagai kelas control kelas sedangkan $\mathrm{IX}_{1}$ sebagai kelas eksperimen.. Instrumen yang digunakan dalam penelitian ini adalah tes hasil belajar peserta didik, berupa pretest dan posttest dan lembar observasi. Teknik analisis data yang digunakan adalah analisis statistik deskriptif dan analisis statistik inferensial. Berdasarkan hasil analisis dengan menggunakan statistik deskriptif pada kelas kontrol yakni nilai rata-rata pretest adalah 60,93 dan nilai rata-rata posttest adalah 65,60 sedangkan kelas eksperimen nilai rata-rata pretest adalah 57,59 dan nilai rata- rata posttest adalah 76,53 kelompok. Berdasarkan hasil analisis inferensial diperoleh niai $t_{\text {hitung }}$ sebesar 3,96 yang lebih besar dari pada $t_{\text {tabel }}$ sebesar 2,00 ( $t_{\text {hitung }}>$ $t_{\text {tabel}}$ ) dan rata-rata hasil belajar kelas eksperimen lebih tinggi dibanding rata-rata hasil belajar kelas kontrol, dengan demikian dapat disimpulkan bahwa $H_{0}$ ditolak karena $t_{\text {hitung }}>t_{\text {tabel }}$ atau 3,96 $>2,00$. Dengan demikian penerapan strategi pembelajaran Student Recap efektif dalam meningkatan hasil belajar matematika peserta didik pada kelas IX MTs Negeri 6 Sleman Kab. Sleman.
\end{abstract}

Kata kunci : hasil belajar, student recap.

\begin{abstract}
This PTK article discusses the effectiveness of implementing Student Recap learning strategies in improving students' mathematics learning outcomes with the aim of knowing how (1) Mathematics learning outcomes of students being taught without using student recap learning strategies in class IX MTs Negeri 6 Sleman Kab. Sleman,
\end{abstract}


(2) Mathematics learning outcomes of students who are taught using the student recap learning strategy in class IX MTs Negeri 6 Sleman Kab. Sleman, (3) Is the application of student recap learning strategies effective in improving the mathematics learning outcomes of class IX students of MTs Negeri 6 Sleman Kab. Sleman. This research is a quasi experimental research design with a non-equivalent control group design. The population of this study were all students of class IX MTs Negeri 6 Sleman Kab. Sleman, with a total of 98 students, consists of class IX1 to class IX3. The sample in this study was class IX3 as the control class while IX1 as the experimental class. The instrument used in this study was a test of student learning outcomes, in the form of a pretest and posttest and an observation sheet. The data analysis technique used is descriptive statistical analysis and inferential statistical analysis. Based on the results of the analysis using descriptive statistics in the control class, namely the average pretest score was 60.93 and the posttest average score was 65.60 while the experimental class pretest average score was 57.59 and the posttest average score was 76. , 53 groups. Based on the results of inferential analysis, the value of tcount is 3.96 which is greater than the t-table of 2.00 ( $\mathrm{t}$-count> t-table) and the average learning outcomes of the experimental class are higher than the average learning outcomes of the control class, thus it can be concluded that $\mathrm{H} 0$ is rejected because tcount $>$ ttable or 3.96>2.00. Thus the application of the Student Recap learning strategy is effective in improving the mathematics learning outcomes of students in class IX MTs Negeri 6 Sleman Kab. Sleman.

Keyword : learning outcomes, student recap.

\section{PENDAHULUAN}

Model pembelajaran dengan pemberian uraian saja, akan menghasilkan anak didik yang kurang kreatif dan menghambat dalam berpikir kritis. Belajar adalah suatu aktivitas yang dilakukan peserta didik, bukan yang dilakukan terhadap peserta didik. Belajar menunjukkan suatu aktivitas pada diri seseorang yang disadari atau disengaja. Oleh sebab itu guru bukanlah satu-satunya sumber ilmu pengetahuan, beliau hadir membantu peserta didik memecahkan masalah, serta mempersiapkan lingkungan belajar yang memungkinkan peserta didik dapat memperoleh pengalaman belajar yang luas (Hasbullah:2006)

Proses belajar mengajar matematika yang baik adalah guru harus mampu menerapkan suasana yang dapat membuat murid antusias terhadap persoalan yang ada sehingga mereka mampu mencoba memecahkan persoalannya. (Senjaya:2008). Proses pembelajaran membutuhkan metode yang tepat. Kesalahan menggunakan metode, dapat menghambat tercapainya tujuan pendidikan yang diinginkan (Amri:2013) Dampak yang lain adalah rendahnya kemampuan bernalar peserta didik dalam pembelajaran matematika. Hal ini disebabkan karena dalam proses belajar mengajar peserta didik kurang dilibatkan dalam situasi optimal untuk belajar.

Pada proses pembelajaran di sekolah, guru tidak hanya dituntut mampu menyampaikan materi dengan baik, tetapi mampu memahami karakteristik peserta didik sehingga tujuan pembelajaran dapat tercapai (Utari dkk:2014). Salah satu materi pelajaran di sekolah adalah matematika. Pembelajaran matematika merupakan 
pembelajaran yang sangat penting bagi peserta didik, matematika merupakan ilmu universal yang mempunyai peran penting dalam kehidupan sehari-hari maupun dalam pengembangan ilmu pengetahuan lainnya. Pembelajaran matematika dikatakan efektif apabila peserta didik memahami konsep dari matematika dan mengaplikasikannya dalam kehidupan sehari-hari. Keberhasilan proses pembelajaran matematika dapat diukur dari tercapainya tujuan pembelajaran matematika (Purwanto:2012). Keberhasilan itu dapat dilihat dari aktivitas guru yang mampu melaksanakan tugasnya dengan baik sebagai mediator, motivator dan fasilitator peserta didik sehingga peserta didik menjadi aktif dan kreatif serta pembelajaran pun menjadi efektif dan menyenangkan.

Namun pada kenyataan di lapangan dapat dilihat bahwa minat belajar peserta didik pada mata pelajaran matematika masih sangat rendah. Salah satu masalah pokok dalam pembelajaran matematika adalah masih rendahnya daya serap peserta didik.Hal ini nampak rerata hasil belajar peserta didik yang senantiasa masih sangat memprihatinkan.Keadaan tersebut tentunya merupakan hasil kondisi pembelajaran yang masih bersifat konvensional dan tidak menyentuh ranah dimensi peserta didik itu sendiri, yaitu bagaimana sebenarnya belajar itu.Selain itu, faktor yang cukup besar mempengaruhi dalam pencapaian hasil belajar adalah cara peserta didik memahami apa yang diajarkan oleh guru tentunya hal initidak terlepas dari cara mengajar seorang guru. Guru adalah pengajar yang mendidik, sebagai pendidikia memusatkan perhatian pada kepribadian peserta didik, khususnya berkenaan dengan kebangkitan belajar. Kebangkitan belajar tersebut merupakan wujud emansipasi diri peserta didik. Berdasarkan uraian di atas penulis terdorong untuk mengkaji lebih jauh dengan mengangkat judul penelitian "Usaha Meningkatkan Hasil Belajar Matematika Dengan Menerapkan Strategi Pembelajaran Student Recap Pada Peserta Didik Pada Kelas IXA MTs Negeri 6 Sleman"

\section{METODE PENELITIAN}

Pendekatan yang digunakan dalam penelitian ini adalah pendekatan kuantitatif, dimana pendekatan kuantitatif merupakan pendekatan yang menggunakan data berupa angka sebagai alat menemukan keterangan mengenai apa yang kita ketahui. Penelitian ini merupakan penelitian eksperimen dengan jenis penelitian quasi experimental. yang dibagi menjadi dua kelompok eksperimen, yaitu kelompok pertama adalah kelompok perlakuan yang menggunakan startegi pembelajaran Student Recap dan kelompok kedua adalah kelompok kontrol yang tidak dikenai perlakuan. Penelitian dilaksanakan MTs Negeri 6 Sleman Jln. Magelang km 4,4 Sinduadi Mlati Sleman, Kabupaten Sleman, Provinsi D.I.Yogyakarta. 


\section{HASIL PENELITIAN DAN PEMBAHASAN}

penelitian.

Berikut hasil penelitian yang penulis dapatkan setelah melakukan

1. Hasil Analisis Statistik Deskriptif

a Deskripsi Hasil Belajar Peserta didik Kelas IX MTs Negeri 6 Sleman Kab. Sleman yang Diajar tanpa Menggunakan Strategi Pembelajaran Student Recap.

Berdasarkan hasil penelitian yang dilakukan di MTs Negeri 6 Sleman Kab. Sleman yang dimulai sejak tanggal 04 Januari sampai dengan 25 Januari 2021, penulis dapat mengumpulkan data melalui instrument test dan memperoleh hasil belajar berupa nilai peserta didik kelas IX MTs Negeri 6 Sleman Kab. Sleman.

Tingkat pengusaan materi peserta didik pada pretest dan posttest sebagai berikut:

a) Pada pretest terdapat (0\%) berada pada kategori sangat rendah, 8 peserta didik $(24,24 \%)$ berada pada kategori rendah, 14 peserta didik $(42,42 \%)$ berada pada kategori sedang, 11 peserta didik $(27,27 \%)$ berada pada kategori tinggi, dan $0 \%$ hasil pretest peserta didik berada pada kategori sangat tinggi atau dapat dikatakan bahwa tidak ada peserta didik yang hasil pretestnya mencapai hasil sangat tinggi.

b) Pada Posttest terdapat 0\% peserta didik berada pada kategori sangat rendah, 7 peserta didik $(21,21 \%)$ berada pada kategori rendah, 8 peserta didik $(24,24 \%)$ berada pada kategori sedang, 17 peserta didik $(51,51 \%)$ berada pada kategori tinggi, dan 1 peserta didik $(3,04 \%)$ yang berada pada kategori sangat tinggi.

Selanjutnya, penulis menyajikan hasil pretest dan posttest guna memperlihatkan perbandingan pada hasil belajar matematika peserta didik Kelas $\mathrm{IX}_{3}$ MTs Negeri 6 Sleman Kab. Sleman sebagai kelas kontrol sebagai berikut:

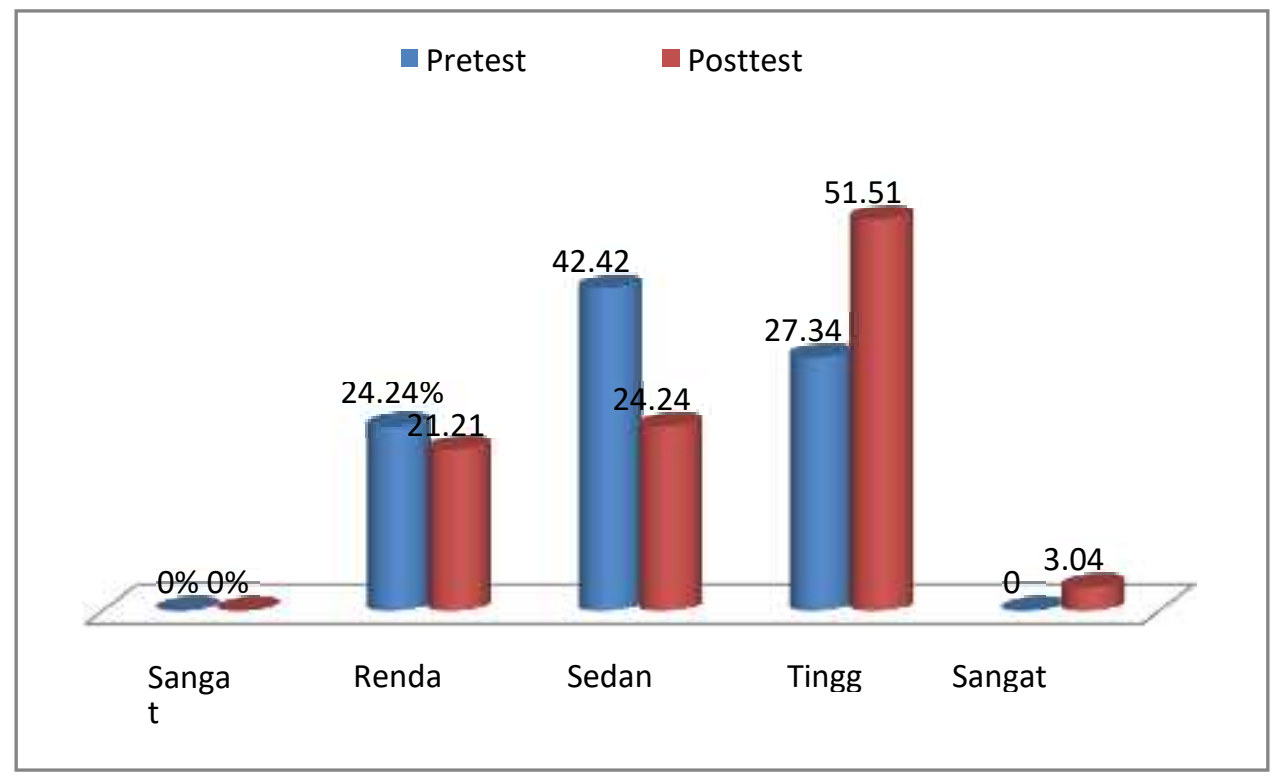

Gambar 1 Diagram Batang Hasil Pretest dan Posttest Kelas Kontrol 
Berdasarkan diagram batang hasil pretest dan posttest di atas dapat kita lihat bahwa persentase terbanyak pada hasil pretest kelas kontrol berada pada kategori sedang, sedangkan persentase terbanyak hasil posttest kelas kontrol berada pada kategori tinggi dan terjadi peningkatan pada kategori sedang dan tinggi.

b. Deskripsi Hasil Belajar Peserta didik Kelas IX MTs Negeri 6 Sleman Kab. Sleman yang Diajar Menggunakan Strategi Pembelajaran Student Recap.

Berikut ini adalah nilai pretest dan posttest peserta didik yang diajar menggunakan strategi pembelajaran Student Recap

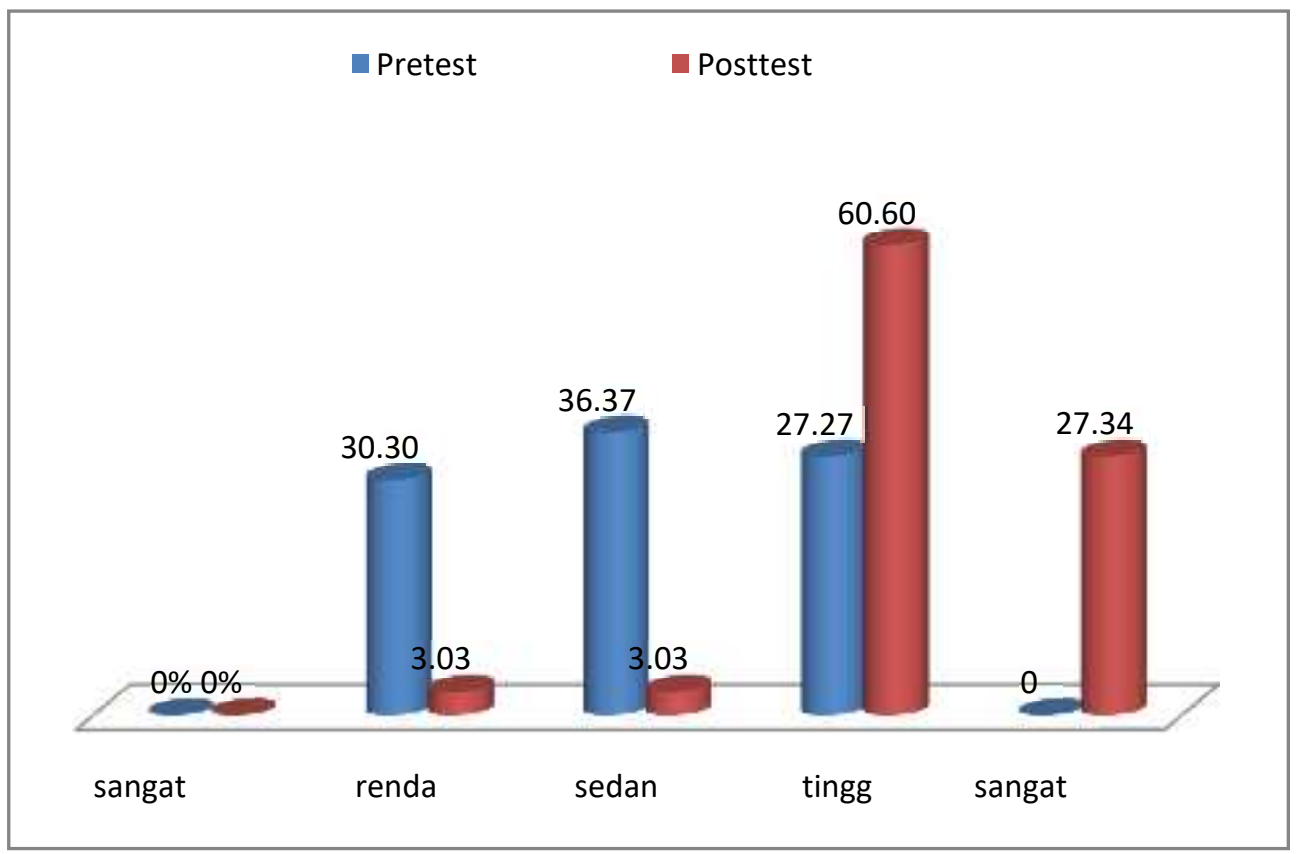

Gambar 2 Diagram Batang Hasil Pretest dan Posttest Kelas Eksperimen

Berdasarkan diagram batang hasil pretest dan posttest di atas dapat kita lihat bahwa persentase terbanyak pada hasil pretest kelas eksperimen berada pada kategori rendah, sedangkan persentase terbanyak hasil posttest kelas eksperimen berada pada kategori tinggi. Pada hasil posttest kelas eksperimen dapat kita lihat bahwa terdapat 20 orang berada pada kategori tinggi dengan persentase $60,60 \%$ sementara pada hasil pretestnya terdapat 12 peserta didik yang berada pada kategori sedang dengan presentase $36,37 \%$. Sedangkan pada kategori sangat tinggi pada hasil posttest kelas eksperimen dapat kita lihat bahwa terdapat 11 peserta didik dengan persentase $27,34 \%$ sementara pada hasil pretestnya tidak terdapat peserta didik yang berada pada kategori sangat tinggi dengan presentase $0 \%$. Peningkatan yang signifikan pada kategori tinggi dan sangat tinggi ini dikarenakan terjadi interaksi yang aktif antar peserta didik pada saat pembelajaran, ini bisa kita lihat pada lembar observasi kelas eksperimen. 


\section{Hasil Analisis Inferensial}

Deskriptif Efektivitas Penerapan Strategi Pembelajaran Student Recap terhadap Hasil Belajar Matematika pada Peserta didik Kelas IX MTs Negeri 6 Sleman Kab. Sleman.

Pada bagian ini akan dibahas mengenai hasil penelitian yang telah diperoleh. Penelitian ini merupakan penelitian Quasi Eksperimen dengan desain penelitian yang digunakan yaitu Non Equivalent Control Group Design yaitu dengan membandingkan kelas eksperimen dengan kelas kelompok control. Kelas eksperimen adalah kelas yang diajar dengan menggunakan strategi pembelajaran Student Recap dan kelas kontrol yang diajar tanpa menggunakan strategi pembelajaran Student Recap.

Setelah melalui proses perhitungan, diperoleh hasil Pretest dan posttest yang telah dilakukan pada masing-masing kelas eksperimen dan kelas kontrol. Dimana Pretest merupakan tes awal yang dilakukan pada masing-masing kelas sebelum diberikannya perlakuan pada kelas eksperimen dan kontrol sedangkan posttest merupakan tes yang dilakukan setelah kelas eksperimen diajar dengan menggunakan strategi pembelajaran Student Recap dan kelas kontrol diajar dengan menggunakan model pembelajaran langsung. Dapat terlihat bahwa pelajaran strategi pembelajaran Student Recap dapat dikatakan efektif dalam meningkatkan hasil belajar matematika peserta didik kelas IX MTs Negeri 6 Sleman.

Hal ini dapat terlihat pada analisis deskriptif dan inferensial yang dilakukan sebelumnya, yaitu hasil analisis tes matematika peserta didik pada kelas kontrol dengan rata-rata nilai hasil pretest yaitu 60,93 dan rata-rata nilai hasil posttest yaitu 65,60 serta selisih rata-rata kenaikan hasil belajar peserta didik adalah 4,67 dengan persentase 7,66\%. Sedangkan hasil analisis deskriptif tes matematika peserta didik pada kelas eksperimen dengan rata-rata nilai hasil pretest yaitu 57,59 dan rata-rata nilai hasil posttest yaitu 76,53 serta selisih ratarata kenaikan hasil belajar peserta didik adalah 18,94 dengan persentase $26,88 \%$

Berdasarkan hasil pemaparan di atas, hasil penelitian menunjukkan bahwa penerapan strategi pembelajaran Student Recap lebih baik dibandingkan dengan tanpa menggunakan strategi pembelajaran Student Recap. Hal ini terjadi karena kelas yang diajar dengan menggunakan strategi pembelajaran Student Recap membuat peserta didik lebih aktif dalam belajar, peserta didik dilatih mandiri dalam belajar yaitu dengan merangkum materi apa yang dipelajarinya, membuat pertanyaan beserta jawabannya, dan kemudain menyajikannya kembali materi yang telah diperoleh kepada peserta didik yang lainnya. Pembelajaran dengan menggunakan strategi pembelajaran Student Recap juga dapat membantu peserta didik mencapai tujuan pembelajaran secara efektif dan efisien serta memungkinkan peserta didik untuk melakukan pembelajaran aktif dan mandiri tanpa bergantung pada guru.

Hasil belajar peserta didik pada kelas kontrol diajar tanpa menggunakan strategi pembelajaran Student Recap lebih rendah dibandingkan kelas eksperimen yang diajar dengan menggunakan strategi pembelajaran Student 
Recap dilihat dari keterlibatan peserta didik tidak terlalu nampak. Peserta didik mempunyai kecenderungan untuk menunggu jawaban dari guru, bahkan mereka tidak berusaha untuk memecahkan soal-soal yang diberikan. Guru lebih aktif daripada peserta didik sehingga membuat peserta didik semakin tergantung kepada guru dan mereka tidak terbiasa belajar sendiri tanpa ada bantuan atau bimbingan dari guru.

Berdasarkan data hasil observasi aktivitas peserta didik pada kelas eksperimen yang diajar menggunakan strategi pembelajaran Student Recap lebih baik dibandingakan hasil observasi aktivitas peserta didik pada kelas kontrol yang diajar tanpa menggunakan strategi pembelajaran Student Recap. Hal ini dapat dilihat dari presentasi rata-rata setiap komponen yang diamati pada hasil observasi kelas eksperimen dan kelas control.

Berdasarkan hasil pengujian statistik inferensial pada uji $\mathrm{t}$ sampel independen diperoleh $t_{\text {hitung }}>t_{\text {tabel }}$ dimana, $t_{\text {hitung }}=3,96$ sedangkan $t_{\text {tabel }}=2,00$ menunjukkan $\mathrm{H}_{0}$ ditolak. Berdasarkan pengujian statistic inferensial tersebut dapat disimpulkan bahwa strategi pembelajaran Student Recap efektif dalam meningkatkan hasil belajar matematika pada peserta didik kelas IX MTs Negeri 6 Sleman Kab. Sleman.

Hasil penelitian ini juga sejalan dengan penelitian yang dilakukan oleh Andi Sultan pada tahun 2010 dengan judul "Pengaruh hasil belajar matematika melalui strategi pembelajaran Student recap pada peserta didik kelas VIIID MTS Negeri 6 Sleman Kabupaten Sleman" mengatakan bahwa hasil belajar setelah diterapkannya strategi pembelajaran Student Recap menunjukkan skor rata-rata nilai peserta didik untuk masing-masing siklus selalu berada di atas nilai standar (Sultan :2010)

Penelitian ini didukung oleh teori Mel Silberman (2007) dan Prince (2004) menyatakan bahwa Strategi ini peserta didik selain dituntut untuk mendengar, membaca, sampai merangkum materi yang telah disajikan oleh guru, peserta didik juga dituntut untuk bisa paham dan mampu mempersentasekan apa yang ditulisnya kepada teman-temannya.

Hasil belajar peserta didik dengan menggunakan strategi pembelajaran Student Recap efektif dalam meningkatkan hasil belajar matematika peserta didik dapat kita lihat pada nilai hasil belajar pada kelas eksperimen lebih tinggi dari pada nilai hasil belajar kelompok kontrol. Penyebabnya karena penggunaan strategi pembelajaran Student Recap efektif dapat meningkatkan antusias peserta didik dalam belajar sehingga dapat meningkatkan hasil belajar peserta didik.

\section{KESIMPULAN DAN SARAN}

\section{a) Kesimpulan}

Berdasarkan hasil analisis data tentang efektivitas penerapan strategi pembelajaran Student Recap dalam meningkatan hasil belajar matematika peserta didik kelas IX MTs Negeri 6 Sleman, maka dapat disimpulkan bahwa:

1. Rata-rata hasil belajar matematika peserta didik kelas IX MTs Negeri 6 
Sleman pada kelas kontrol sebelum diajar tanpa menggunakan strategi pembelajaran Student Recap adalah 60,93 dan setelah diajar tanpa menggunakan strategi pembelajaran Student Recap adalah 65,60. Terjadi peningkatan sebesar 4,67 dengan persentase sebesar 7,66\%.

2. Rata-rata hasil belajar matematika peserta didik kelas IX MTs Negeri 6 Sleman pada kelas eksperimen sebelum penggunaan strategi pembelajaran Student Recap adalah 57,59 dan setelah penggunaan strategi pembelajaran Student Recap adalah 776,53 . Terjadi peningkatan sebesar 18,94 dengan persentase sebesar 26,88\%.

3. Berdasarkan hasil analisis inferensial diperoleh $t_{\text {hitung }}>t_{\text {tabel }}$ dimana, $t_{\text {hitung }}$ $=3,96$ sedangkan $\mathrm{t}_{\text {tabel }}=2,00$ menunjukan $\mathrm{H}_{0}$ ditolak. Berdasarkan kriteria pengujian tersebut dapat dikatakan bahwa strategi pembelajaran Student Recap efektif dalam meningkatkan hasil belajar matematika pada peserta didik kelas IX MTs Negeri 6 Sleman.

\section{b) Saran}

1. Kepada guru matematika di seluruh Indonesia khususnya guru matematika di MTs Negeri 6 Sleman agar dalam pembelajaran matematika disarankan untuk mengajar dengan menerapakan strategi pembelajaran Student Recap.

2. Kepada penentu kebijakan dalam bidang pendidikan agar hasil penelitian ini dapat dijadikan bahan pertimbangan dalam rangka meningkatkan mutu pendidikan di Sekolah terkhusus MTs Negeri 6 Sleman.

3. Penulis menyadari masih banyak kekurangan dalam penelitian dan penyusunan skirpsi ini, jadi diharapkan kepada peneliti lain untuk menyelidiki variable-variabel yang relevan pada materi dengan situasi dan kondisi yang berbeda sehingga gilirannya nanti akan lahir satu tulisan yang lebih baik, lengkap dan bermutu.

\section{DAFTAR PUSTAKA}

Andi Sultan, 2010."Peningkatan Hasil Belajar Matematika Melalui Strategi Pembelajaran Student Recap pada Siswa Kelas VIIID SMP Negeri 2 Palangga Kab. Makassar" ,PTK.

Baharuddin, dkk, 2007. Teori Belajar dan Pembelajaran. Jogjakarta: ArJakarta: CV Toha Putra.

Ihsan Senjaya, 2011. Dasar-Dasar Kependidikan. Jakarta: RinekaCipta.

Hasbullah, 2006. Dasar-dasar Ilmu Pendidikan. Jakarta: PT Raja Grafindo Persada,)

Mel Silberman, 2007. Active Learning: Active Student Learning. Bandung: Nusamedia.

Michael Prince, 2004. " A type of student recap active learning “. Journal Engr. Education No 93(3).

Mulya Suci Utari dkk, 2014. “ Pengaruh Penerapan Bahan Ajar Fisika Bermuatan Karakter Dalam Strategi Pembelajaran Student Recap Terhadap Hasil 
Belajar Siswa Kelas VIII SMPN 12 Padang", Jurnal Pillar of Physics Education, Vol. 2.

Ngalim Purwanto, 2012. Prinsip-prinsip dan Teknik Evaluasi Pengajaran. Bandung: PT. Remaja Rosdakarya.

Rusman, 2012. Belajar dan Pembelajaran Berbasis Komputer. Bandung: Alfabeta. Sari HadriYani, 2010."Penerapan Model Pembelajaran kooperatif Tipe Team Game Tournament dengan strategi Student Recap pada pembelajaran Matematika SiswaKelas VIII SMP Negeri 25 Padang"PTK.

Sofan Amri, 2013. Peningkatan Mutu Pendidikan Sekolah Dasar dan Menengah. Jakarta: PT. Prestasi Pustakaraya. 